\title{
Calcium stores in differentiated Dictyostelium discoideum: prespore cells sequester calcium more efficiently than prestalk cells
}

\author{
C. Schlatterer, ${ }^{1}$ P. Walther, ${ }^{2}$ M. Müller, ${ }^{3}$ K. Mendgen, ${ }^{1}$ K. Zierold, ${ }^{4}$ \\ G. Knoll ${ }^{1}$ \\ ${ }^{1}$ Faculty of Biology, University of Konstanz, Konstanz, Germany \\ ${ }^{2}$ Section Electron Microscopy, University of Ulm, Albert Einstein Allee 11, Ulm, Germany \\ ${ }^{3}$ Laboratory for EM I, ETH Zürich, Schmelzbergstr. 7, Zürich, Switzerland \\ ${ }^{4}$ Max Planck Institute for Molecular Physiology, Otto Hahn Str. 11, Dortmund, Germany
}

Summary Dictyostelium discoideum pseudoplasmodia exhibit a gradient of the cytosolic free $\mathrm{Ca}^{2+}$-concentration $\left(\left[\mathrm{Ca}^{2+}\right]_{\mathrm{i}}\right)$ along their anterior-posterior axis involved in cell-type specific differentiation. $\left[\mathrm{Ca}^{2+}\right]_{\mathrm{i}}$ is high in prestalk and low in prespore cells. We determined the content and localization of calcium and other elements in cryosectioned cells of pseudoplasmodia and fruiting bodies by X-ray microanalysis. Granular stores rich in $\mathrm{Ca}, \mathrm{Mg}$ and $\mathrm{P}$ were identified. Average Ca was higher in prespore than prestalk granules (225 vs $111 \mathrm{mmol} / \mathrm{kg}$ dry weight). Total Ca stored in granules was also higher in prespore than prestalk cells. The amount of $\mathrm{P}$ and $\mathrm{S}$ in granules differed between the two cell types indicating different store composition. In spores mean granular Ca was $120 \mathrm{mmol} / \mathrm{kg}$ dry weight. Stalk cells had

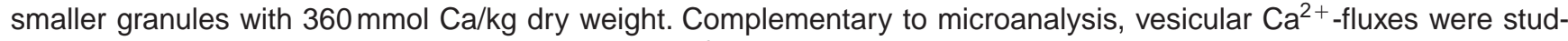
ied in fractionated cell homogenates. The rate of $\mathrm{Ca}^{2+}$-uptake was higher in pellet fractions of prespore than prestalk amoebae $\left(4.7 \mathrm{vs} 3.4 \mathrm{nmol} / \mathrm{min} \times \mathrm{mg}\right.$ ). $\mathrm{Ca}^{2+}$-release was greater in supernatant fractions from prestalk than prespore cells ( $16.5 \mathrm{vs} 7.7 \mathrm{nmol} / 10^{8}$ cells). In summary, prestalk and prespore cells possess qualitatively different, high-capacity stores containing distinct amounts of $\mathrm{Ca}$ and probably being involved in regulation of the anterior-posterior $\left[\mathrm{Ca}^{2+}\right]_{i-}$ gradient. (C) 2001 Harcourt Publishers Ltd

\section{INTRODUCTION}

During the life cycle of Dictyostelium discoideum starving cells aggregate to form a slug-like pseudoplasmodium and predifferentiate essentially to two cell types, prespore and prestalk cells. In the fruiting body terminally differentiated cells have distinct functions. Genetically dead cells comprise the stalk which supports the spore head of the sorus. Under favourable conditions spores germinate and start the cycle again.

Received 7 July 2000

Revised 27 October 2000

Accepted 27 October 2000

Published online 9 January 2001

Correspondence to: Dr Christina Schlatterer, Faculty of Biology, University of Konstanz, 78457 Konstanz, Germany. Tel.: + 497531882479 ;

fax: + 497531 882966; e-mail: Christina.Schlatterer@uni-konstanz.de
Aggregation is accomplished by chemotaxis of amoebae towards the attractant cAMP. The signalling cascade that is activated after binding of cAMP to the cell surface receptor [1] involves a transient increase in the cytosolic free calcium concentration $\left(\left[\mathrm{Ca}^{2+}\right]_{\mathrm{i}}\right)[2]$, which is necessary for chemotactic orientation and migration [3]. $\mathrm{Ca}^{2+}$ release from internal stores is sufficient to generate this $\left[\mathrm{Ca}^{2+}\right]_{\mathrm{i}}$-elevation [3].

In aggregated cells high-capacity $\mathrm{Ca}^{2+}$-stores were detected by X-ray microanalysis [4]. Biochemical and pharmacological results point to the existence of at least two different storage compartments, the $\mathrm{IP}_{3}$-sensitive [5] and an acidic $\mathrm{Ca}^{2+}$-store. The latter is acidified by the activity of a V-type $\mathrm{H}^{+}$-ATPase. The resulting $\mathrm{H}^{+}$-gradient serves to sequester $\mathrm{Ca}^{2+}$ [6]. $\mathrm{Ca}^{2+}$ is released from the acidic store by fatty acids [7]. The properties of acidic vesicles, e.g. the sensitivity of their $\mathrm{H}^{+}$-ATPase towards 
specific inhibitors [7], are very similar to those of acidocalcisomes identified in Trypanosoma [8,9].

In post-aggregation stages of development $\mathrm{Ca}^{2+}$ is involved in cell-type-specific gene expression. Total and sequestered $\mathrm{Ca}^{2+}$ and basal $\left[\mathrm{Ca}^{2+}\right]_{\mathrm{i}}$ were reported to be higher in prestalk than in prespore amoebae [10-12]. Experiments with $\mathrm{Ca}^{2+}$-ATPase inhibitors and $\mathrm{Ca}^{2+}$ chelating agents [13] showed that elevated $\left[\mathrm{Ca}^{2+}\right]_{\mathrm{i}}$-levels enhance prestalk gene induction. These results support the view that an unequal distribution of $\mathrm{Ca}^{2+}$ in the slug is necessary for cell-type-specific differentiation and that $\mathrm{Ca}^{2+}$ is required especially for stalk-cell development [14]. However, an inhibitory effect of $\mathrm{Ca}^{2+}$-antagonists also on cAMP-activated expression of prespore specific genes was found [15]. Incubation of cells with agents that deplete cellular $\mathrm{Ca}^{2+}$ reduced both, prestalk and prespore gene expression to the same extent $[16,17]$. These findings argue against a major role of variations in $\left[\mathrm{Ca}^{2+}\right]_{i}$ between the cell types for differential gene expression.

Experiments supporting the above model, i.e. that total and sequestered $\mathrm{Ca}^{2+}$ is higher in prestalk than prespore amoebae, suffer from potential methodological pitfalls. Chemical fixation was used to analyze the distribution of $\mathrm{Ca}^{2+}$ in slugs autoradiographically [10]. This technique can lead to gross redistribution of diffusible elements [18]. Chlorotetracycline (CTC) which was applied to detect sequestered $\mathrm{Ca}^{2+}$ [11] also binds $\mathrm{Mg}^{2+}$ [19]. In storage compartments of aggregated cells $\mathrm{Mg}$ was found at several times higher concentrations than $\mathrm{Ca}$ [4].

In this study we analyzed the Ca distribution in prespore and prestalk cells and in mature spores and stalks. For localization of diffusible elements, cryofixation was shown to be the most appropriate immobilization technique $[20,21]$. Various rapid-freezing techniques are available to immobilize cell monolayers or droplets of cell suspensions with good structural preservation [22]. For cryofixation of bulk biological samples such as pseudoplasmodia high pressure freezing has to be applied [23]. Slugs and fruiting bodies were high-pressure frozen. In addition, spores and stalks were rapid-frozen by plunging into liquid propane. Freeze-dried cryosections were analyzed by quantitative, energy dispersive $\mathrm{X}$-ray microanalysis. In addition, $\mathrm{Ca}^{2+}$-uptake studies were done with partially purified vesicular fractions from homogenized prestalk and prespore amoebae. Our results show that both prestalk and prespore cells store large amounts of $\mathrm{Ca}^{2+}$ in high capacity compartments which are qualitatively different between the two cell types.

\section{MATERIALS AND METHODS}

\section{Cell culture and induction of development}

Wild-type strain $\mathrm{A} \times 2$ was grown in axenic medium as described [7]. Differentiation was induced by washing cells in cold Sørensen phosphate buffer $(17 \mathrm{mM} \mathrm{K} / \mathrm{Na}-$ $\mathrm{PO}_{4}, \mathrm{pH}$ 6.0; SP-buffer). Cells $\left(2 \times 10^{7} / \mathrm{ml}\right)$ were stained with neutral red $(0.2 \mathrm{mg} / \mathrm{ml})$ for $1 \mathrm{~min}$, followed by washing $3 \times$ with SP-buffer. $1 \mu 1$ cell suspension $(+0.5 \mathrm{mM}$ $\mathrm{Ca}^{2+}$ ) was placed on an aluminum holder filled with $0.7 \%$ SP-agar $\left(+0.5 \mathrm{mM} \mathrm{Ca}^{2+}\right.$; soft agar). Alternatively, $5 \mathrm{ml}$ cell suspension $\left(+2-4 \mathrm{mM} \mathrm{Ca}^{2+}\right)$ were pipetted onto $1.5 \%$ SP-agar in petri dishes. The supernatant was removed $20-30 \mathrm{~min}$ later; cells were incubated in a humid chamber $\left(18 \mathrm{~h}\right.$ at $23^{\circ} \mathrm{C}$ in the dark).

\section{Cryofixation}

Pseudoplasmodia were cryofixed with a HPM 010 (BalTec) high-pressure freezing device. Slugs were oriented prior to freezing. This was facilitated by the reddish colour of the prestalk zone after neutral red staining. Slugs were pushed into the soft agar with the prestalk or prespore zone facing the air. Alternatively, empty holders were placed close to a slug on a petri dish and filled with agar blocks. Slugs were put into the holders in an oriented way. A holder filled with hexadecene was placed on top. Directly afterwards, the sample was high-pressure frozen and stored in liquid nitrogen. Figure 1 shows a schematic drawing of the procedure. Fruiting bodies were collected from a petri dish and spores were separated from stalks by vortexing in SP-buffer. After centrifugation in an Eppendorf centrifuge aliquots of the spore-containing pellet and stalks remaining in the supernatant were put in holders and high-pressure frozen. Spores and stalks
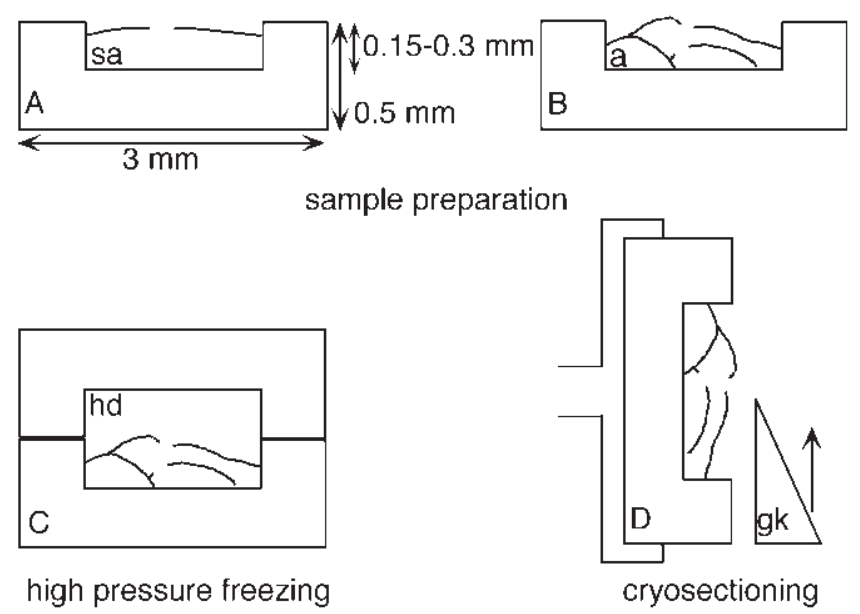

Fig. 1 Schematic drawing showing sample preparation. (A) Aluminum holders were filled with soft agar (sa). Cells developed in the holders; then slugs were pressed into the soft agar with the prestalk or prespore zone facing the air. (B) Agar blocks (a) were placed in an empty holder; slugs from a petri dish were put into the holder. (C) Hexadecene (hd)-filled holders covered samples for high-pressure freezing. (D) After removal of hexadecene, samples were cryosectioned with a glass knife (gk). 
were also rapidly frozen by plunging into liquid propane with a home-made pressurized air-driven plunging device. Spore heads and stalks were separated by using fine tweezers, placed on gold holders $(\varnothing: 0.5 \mathrm{~mm})$ and frozen immediately.

\section{Cryosectioning and X-ray analysis}

Sectioning and analysis was done as outlined before [4]. In brief, after removal of hexadecene from the slugs clear to whitish ultrathin cryosections $(70-80 \mathrm{~nm}$ thickness) were cut with a FC4 Ultracut cryoultramicrotome (Reichert). Handling of the samples was done at -140 to $-150^{\circ} \mathrm{C}$; sections were cut at -125 to $-135^{\circ} \mathrm{C}$. After freeze-drying in the cryotransfer chamber dry sections were imaged and analyzed with an Elmiskop ST $100 \mathrm{~F}$ (Siemens) scanning transmission electron microscope (STEM) equipped with a cold stage at $-135^{\circ} \mathrm{C}$ with a $100 \mathrm{keV}$ electron beam of $1.4 \mathrm{nA}$. For X-ray microanalysis a SiLi detector (Nuclear Semiconductor) combined with a multichannel analyzer (Link systems) was used. Dry (d) and wet weight portions (w) and the wet weight concentrations of $\mathrm{Ca}$ (mmol/ $\mathrm{kg}$ wet weight) were calculated according to Zierold [24] and Zierold [25]. Dry weight amounts of elements $\left(C_{d}\right)$ were obtained by quantitative evaluation of the $\mathrm{X}$-ray spectra according to the peakto-continuum method using the Link Quantem FLS program. To calculate the water content of subcompartments of cells, the dry-weight portion (d) was determined from measurements of the annular dark field intensity using equation:

$$
\mathrm{d}=\mathrm{C} \times\left(\left(\mathrm{I}_{\mathrm{o}} / \mathrm{I}_{\mathrm{f}}\right)-1\right)
$$

according to Zierold [24]. $\mathrm{I}_{\mathrm{o}}$ and $\mathrm{I}_{\mathrm{f}}$ represent the dark field intensity of the organelle and of the support film which is linearly correlated with mass density; c denominates a calibration constant (0.25; taken from [25]). The water content $(\mathrm{w})$ is $\mathrm{w}=1-\mathrm{d}$. Wet-weight concentrations of $\mathrm{Ca}^{2+}\left(\mathrm{C}_{\mathrm{a}}\right)$ were calculated using equation:

$$
\mathrm{C}_{\mathrm{a}}=\mathrm{C}_{\mathrm{d}} \times \mathrm{d} / \mathrm{w}
$$

At high mass density the correlation with dark field intensity is no longer linear. Therefore, organelles with a relative dark field intensity of $\mathrm{I}_{\mathrm{o}} / \mathrm{I}_{\mathrm{f}}>3.5$ were excluded from calculations of mean aqueous $\mathrm{Ca}^{2+}$-concentrations. $\mathrm{Ca}$ in an aqueous environment should be present in its ionic form, therefore wet-weight concentrations are given as wet weight or aqueous $\mathrm{Ca}^{2+}(\mathrm{mM})$. Statistical analysis was done using the Mann-Whitney rank sum test or Student's $t$-test.

\section{Staining of pseudoplasmodia with rhodamine 123}

Slugs were incubated in rhodamine $123(10 \mu \mathrm{g} / \mathrm{ml})$ for $10 \mathrm{~min}$ as described [26]. Slugs were washed with
SP-buffer at least $6 \times$; otherwise background fluorescence led to fluorescence patterns as observed earlier [26]. Slugs were viewed with an inverted microscope (Zeiss) using a standard FITC filter set (AHF).

\section{$\mathrm{Ca}^{2+}$-uptake experiments}

Slugs were dissociated in ice cold SP-buffer $+20 \mathrm{mM}$ EDTA, pH 7.0, by passage through the needle of a syringe. Single cells were washed once, resuspended in SP-buffer and centrifuged on a Percoll gradient (Percoll/ $1.5 \mathrm{M} \mathrm{NaCl}: 9 / 1$; vol/vol) for $30 \mathrm{~min}$ at $27000 \mathrm{~g}$ and at $4^{\circ} \mathrm{C}$. The upper prestalk (low density) and lower prespore (high density) cell band was removed, diluted with cold SP-buffer and centrifuged once. The cell pellet was adjusted to $2 \times 10^{8}$ cells $/ \mathrm{ml}$ in $20 \mathrm{mM}$ Hepes, $\mathrm{pH} 7.2$. Cells were lysed by passage $(4-7 \times)$ through a nuclepore filter. Subsequent treatment and measurement of $\mathrm{Ca}^{2+}$-fluxes was exactly as described [7]. $\mathrm{Ca}^{2+}$-uptake and release was analyzed in the pellet or supernatant from the centrifugation step at $12000 \mathrm{~g}$ using the indicator Fura-2. Protein concentrations of the pellet and supernatant were determined with the 'Coomassie protein assay reagent' (Pierce) with bovine serum albumin as standard.

\section{Imaging of free cytosolic $\mathrm{Ca}^{2+}\left(\left[\mathrm{Ca}^{2+}\right]_{\mathrm{i}}\right)$}

Imaging of the cytosolic free $\mathrm{Ca}^{2+}$ concentration in slugs was done as outlined previously [2]. In brief, amoebae

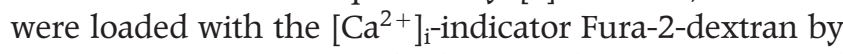
electroporation at $t_{1}$. Washed, labelled cells were mixed with unlabelled amoebae (in SP-buffer or in SP-buffer + $2 \mathrm{mM} \mathrm{CaCl}_{2}$ ) and aliquots of the suspension were pipetted on glass coverslips. Samples were incubated in a humid chamber in the dark for $18-22 \mathrm{~h}$. Subsequently, imaging of basal $\left[\mathrm{Ca}^{2+}\right]_{i}$ in cells in the prestalk or prespore zone was performed on the stage of an inverted microscope (Zeiss) with an intensified CCD-camera as described [2].

\section{RESULTS}

\section{Imaging of cells at different stages of development}

Cryosections were imaged in the STEM in the brightfield/darkfield mode. The contrast is solely due to differences in mass density. Cells of high-pressure frozen slugs appeared compacted with minute extracellular space (Figs 2A \& B). Dark, mass dense granules (MDG) were found in prespore and prestalk cells. These organelles were spread throughout the cells, yet also occurred in clusters (Fig. 2A, inset). In prespore cells their diameter was $270 \pm 13 \mathrm{~nm}($ mean \pm SEM, $n=104)$ which was significantly smaller than in prestalk cells 

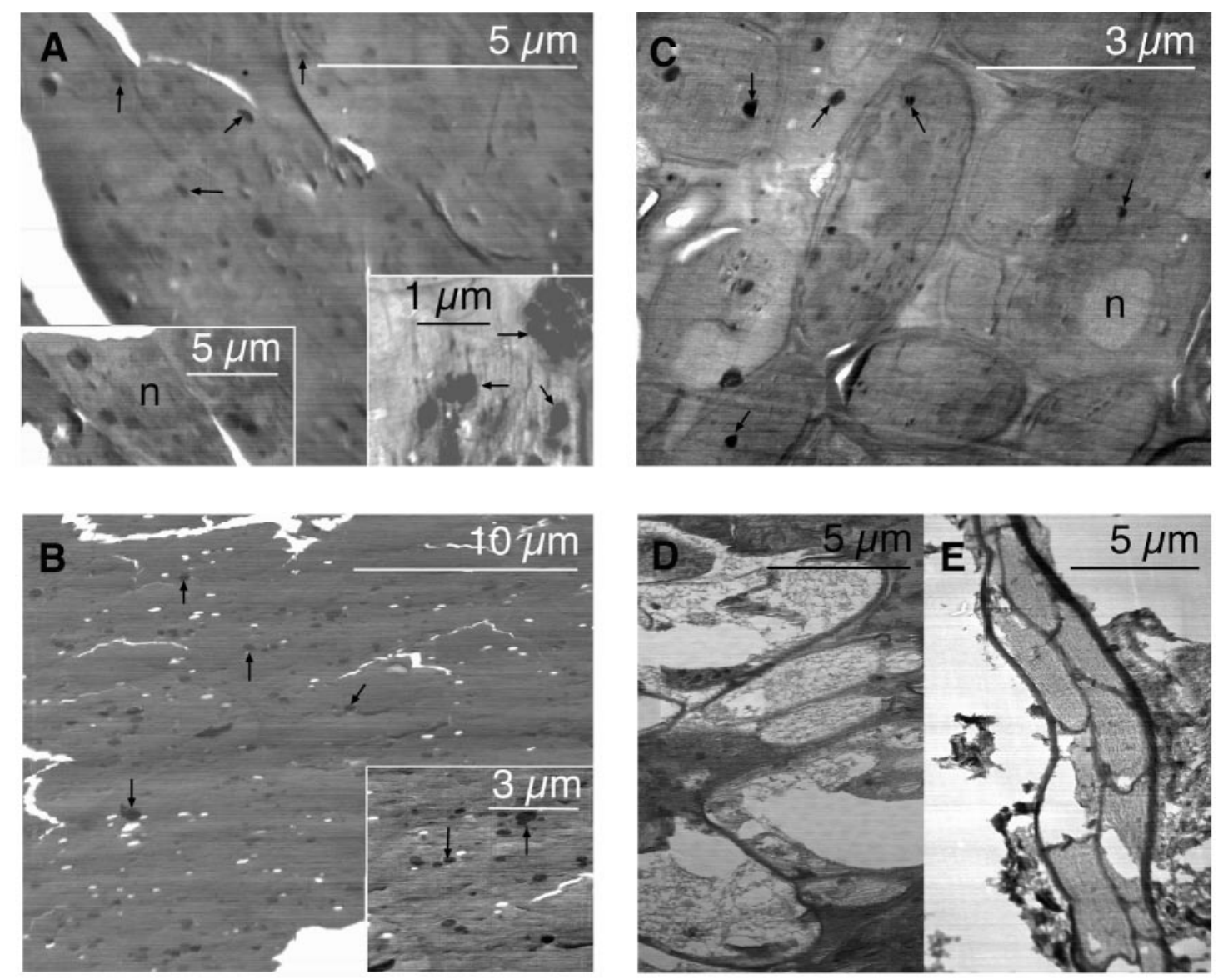

Fig. 2 Electron micrographs of dry sections of cryofixed cells at late stages of development. Image contrast is solely due to mass density of structures. High-pressure frozen prespore (A) and prestalk (B) cells are in close contact. Dark, mass dense granules (MDG) are visible (arrows). The left-hand inset in (A) shows a prespore cell. The right-hand inset depicts a cluster of MDGs; due to their high density the image was brightened up. Inset in (B) shows prestalk MDGs. In spores (C, rapidly frozen) MDGs are present (arrows). Rapidly frozen (D) and high pressure frozen (E) stalk cells appear rather homogeneous. In (E) the stalk tube is visible. n: nucleus.

$(411 \pm 19 \mathrm{~nm}$, mean \pm SEM, $n=78)$. In spores (Fig. 2C) the spore coat and cell compartments including MDGs were discernible. Rapid freezing did not evoke significant ice crystal formation in the small, dense and densely packed spore cells. In the aqueous stalk cells cryofixed by rapid freezing some ice-crystal formation occurred. In general, in stalk cells (Figs 2D \& E) internal structures were barely visible. The cells appeared rather homogeneous. Light areas might represent the stalk vacuole, but could also be due to rupture of the section at these sites. Mass dense structures were present, yet they were not as prominent as in the other cells and were smaller, with a diameter less than $50 \mathrm{~nm}$.

\section{Quantitative X-ray microanalysis of elements in cell compartments}

The content of various elements was determined in different cell compartments, the cytosol, nuclei, mitochondria and MDGs. Quantitation of the element analysis in prespore and prestalk amoebae, and in spores and stalks is summarized in Tables 1 and 2.

In the cytosol the level of dry-weight Ca was significantly higher in prestalk than in prespore cells $(10.3 \pm$ $2 \mathrm{mmol} / \mathrm{kg}$ dry weight vs $6.3 \pm 1 \mathrm{mmol} / \mathrm{kg}$ dry weight, mean \pm SEM). Yet their cytosolic water portion was also higher than in prespore cells, so wet weight total cytosolic $\mathrm{Ca}^{2+}$ was not different (Table 3). By contrast, basal free cytosolic $\mathrm{Ca}^{2+}$ of amoebae, determined by $\left[\mathrm{Ca}^{2+}\right]_{\mathrm{i}^{-}}$ imaging of prespore and prestalk regions in pseudoplasmodia using Fura-2-dextran, was higher in the prestalk than the prespore zone $(93 \pm 14 \mathrm{nM}$ vs $53 \pm 2 \mathrm{nM}$, respectively; mean \pm SEM; $n=10$ each). The dry-weight amounts of other cytosolic elements were similar in both cell types and in the range of that observed in aggregated cells [4]. The same holds true for the element contents of nuclei, except for the level of $\mathrm{S}$ which was lower in prestalk than prespore cells. In spores dry-weight total Ca in 
Table 1 Element contents of different compartments in prespore and prestalk amoebae

\begin{tabular}{|c|c|c|c|c|c|c|c|}
\hline $\begin{array}{l}\text { Cell type } \\
\text { Compartment }\end{array}$ & Sodium & Magnesium & Phosphorus & Sulfur & Chloride & Potassium & Calcium \\
\hline \multicolumn{8}{|l|}{ Prespore } \\
\hline Cytosol (25) & $35 \pm 6$ & $47 \pm 4$ & $602 \pm 24$ & $142 \pm 8$ & $18 \pm 2$ & $160 \pm 13$ & $6.3 \pm 1$ \\
\hline Nucleus (16) & $61 \pm 11$ & $36 \pm 5$ & $453 \pm 32$ & $201 \pm 13$ & $24 \pm 5$ & $222 \pm 15$ & $6.6 \pm 3$ \\
\hline Mitochondrion (28) & $19 \pm 5$ & $26 \pm 3$ & $459 \pm 26$ & $137 \pm 7$ & $4 \pm 1$ & $64 \pm 8$ & $2.6 \pm 1$ \\
\hline MDG (50) & $24 \pm 5$ & $426 \pm 62$ & $875 \pm 60$ & $81 \pm 6$ & $8 \pm 1$ & $116 \pm 11$ & $4.8 \pm 1$ \\
\hline Ca-MDG (63) & $40 \pm 10$ & $502 \pm 37$ & $1993 \pm 108$ & $94 \pm 9$ & $8 \pm 1$ & $96 \pm 7$ & $225 \pm 24$ \\
\hline \multicolumn{8}{|l|}{ Prestalk } \\
\hline Cytosol (20) & $20 \pm 4$ & $54 \pm 5$ & $549 \pm 41$ & $130 \pm 5$ & $18 \pm 3$ & $150 \pm 15$ & $10.3 \pm 2$ \\
\hline Nucleus (4) & $(-)$ & $40 \pm 8$ & $385 \pm 49$ & $92 \pm 8$ & $23 \pm 6$ & $168 \pm 31$ & $7.8 \pm 3$ \\
\hline \multicolumn{8}{|l|}{ Mitochondrion } \\
\hline MDG (14) & $(-)$ & $336 \pm 107$ & $1105 \pm 229$ & $66 \pm 11$ & $14 \pm 5$ & $115 \pm 23$ & $5.3 \pm 2$ \\
\hline Ca-MDG (54) & $(-)$ & $588 \pm 56$ & $2921 \pm 292$ & $58 \pm 8$ & $23 \pm 4$ & $105 \pm 12$ & $111 \pm 14$ \\
\hline
\end{tabular}

Values are $\mathrm{mmol} / \mathrm{kg}$ dry weight (mean \pm SEM from at least two independent experiments). Mass dense granules (MDG) were divided in two groups (MDG: $\leq 20 \mathrm{mmol} \mathrm{Ca} / \mathrm{kg}$ dry weight; Ca-MDG: $>20 \mathrm{mmol} \mathrm{Ca} / \mathrm{kg}$ dry weight).

Number of samples analyzed is indicated in brackets. (-): values below the detection limit.

Table 2 Element contents of different compartments in mature spores and stalk cells

\begin{tabular}{lcccccrr}
\hline $\begin{array}{l}\text { Cell type } \\
\text { Compartment }\end{array}$ & Sodium & Magnesium & Phosphorus & Sulfur & Chloride & Potassium & Calcium \\
\hline Spore & & & & & & & \\
Cytosol (16) & $38 \pm 7$ & $44 \pm 6$ & $484 \pm 36$ & $133 \pm 10$ & $44 \pm 7$ & $165 \pm 23$ & $6.5 \pm 2$ \\
Nucleus (15) & $29 \pm 7$ & $39 \pm 7$ & $514 \pm 40$ & $171 \pm 10$ & $59 \pm 8$ & $200 \pm 15$ & $10.8 \pm 7$ \\
Mitochondrion (15) & $(-)$ & $37 \pm 9$ & $377 \pm 65$ & $143 \pm 28$ & $18 \pm 2$ & $65 \pm 19$ & $3.8 \pm 1$ \\
MDG (16) & $(-)$ & $760 \pm 176$ & $1529 \pm 338$ & $88 \pm 13$ & $39 \pm 13$ & $136 \pm 28$ & $6.1 \pm 2$ \\
Ca-MDG (22) & $(-)$ & $717 \pm 138$ & $2297 \pm 217$ & $58 \pm 15$ & $22 \pm 5$ & $121 \pm 31$ & $120 \pm 17$ \\
Stalk & & & & & & & \\
Cytosol (10) & $(-)$ & $105 \pm 30$ & $1166 \pm 135$ & $313 \pm 28$ & $186 \pm 39$ & $955 \pm 316$ & $13.1 \pm 6$ \\
Nucleus & & & & & & & \\
Mitochondrion & $(-)$ & $363 \pm 175$ & $830 \pm 185$ & $120 \pm 12$ & $22 \pm 3$ & $189 \pm 31$ & $3.8 \pm 1$ \\
MDG (8) & $47 \pm 11$ & $134 \pm 25$ & $1027 \pm 126$ & $142 \pm 21$ & $63 \pm 12$ & $113 \pm 23$ & $360 \pm 90$ \\
Ca-MDG (11) & & & & & & & \\
\hline
\end{tabular}

Values are $\mathrm{mmol} / \mathrm{kg}$ dry weight (mean \pm SEM from two independent experiments). MDGs were divided in two groups (MDG and Ca-MDG) as described in Table 1. Number of samples analyzed is indicated in brackets. (-): values below the detection limit. In stalks, neither nuclei nor mitochondria were discernible. Mass dense structures in stalk cells differed in size from the MDGs of the other cell types; nevertheless, their element content was listed in the sectors MDG and Ca-MDG.

Table 3 Dry and wet weight portions and aqueous $\mathrm{Ca}^{2+}$ in the cytosol and Ca-MDGs of prespore and prestalk amoebae

\begin{tabular}{|c|c|c|c|c|c|c|}
\hline \multirow[t]{2}{*}{ Cell type } & \multicolumn{3}{|c|}{ Cytosol } & \multicolumn{3}{|c|}{ Ca-MDG } \\
\hline & d & $\mathbf{w}$ & $\begin{array}{l}\text { aqueous } \\
\mathrm{Ca}^{2+}(\mathrm{mM})\end{array}$ & d & $\mathbf{w}$ & $\begin{array}{l}\text { aqueous } \\
\mathrm{Ca}^{2+}(\mathrm{mM})\end{array}$ \\
\hline Prespore & $0.23 \pm 0.02$ & $0.77 \pm 0.02$ & $2.02 \pm 0.7(17)$ & $0.34 \pm 0.02$ & $0.66 \pm 0.02$ & $202 \pm 67(46)$ \\
\hline Prestalk & $0.21 \pm 0.03$ & $0.79 \pm 0.03$ & $2.42 \pm 0.7(18)$ & $0.27 \pm 0.01$ & $0.73 \pm 0.01$ & $39 \pm 5(53)$ \\
\hline
\end{tabular}

The portion of dry (d) and wet (w) weight and resulting total aqueous $\mathrm{Ca}^{2+}$ (mean \pm SEM) in the compartments was calculated from the relative dark field intensities as described [25]. Numbers in brackets indicate numbers of samples.

the cytosol was comparable to prespore amoebae. In mature stalk cells the cytosolic element content differed from that of the other cell types. In both high pressure and rapidly frozen samples the measuring window had a size of $0.8(\mu \mathrm{m})^{2}$ which by far exceeded critical ice crystal size. In most cases cytosolic element contents in stalk cells were significantly increased, probably caused by leakiness of the dead cells. Cell compartments, e.g. nuclei or mitochondria were not visible, presumably due to disintegration. 


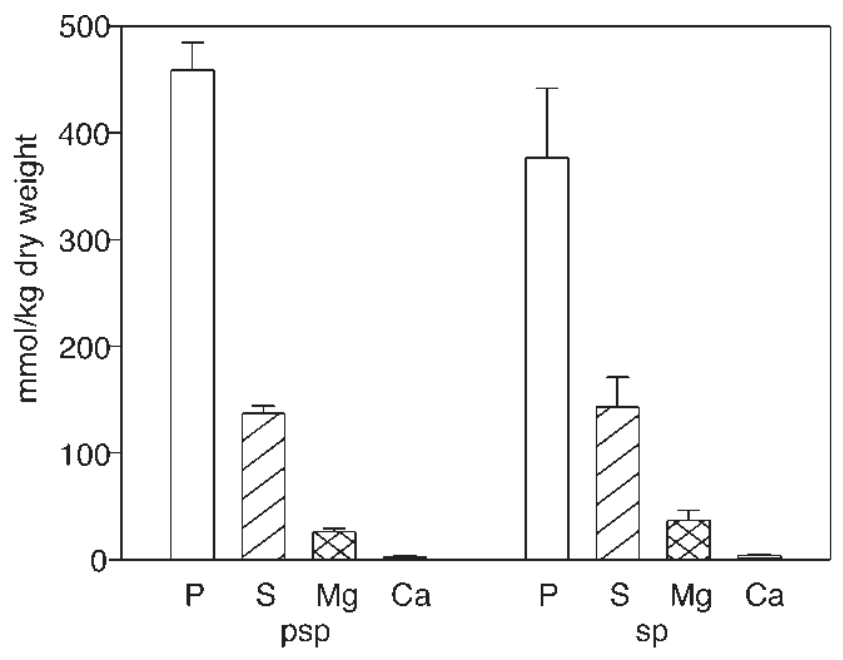

Fig. 3 Comparison of mitochondrial P, S, Mg and $\mathrm{Ca}$ in prespore (psp) and spore (sp) cells. Dry-weight amounts of elements (mean \pm SEM; $\mathrm{mmol} / \mathrm{kg}$ dry weight) are plotted. The ratio of $\mathrm{P} / \mathrm{S}$ of $2-3$ is typical for mitochondria.

Mitochondria have characteristic X-ray spectra with low amounts of $\mathrm{P}, \mathrm{Mg}$ and $\mathrm{Ca}$ and a comparatively high level of $S$; the ratio of $\mathrm{P} / \mathrm{S}$ is in the range of $2-3[24,27$, 28]. Such spectra were recorded in prespore cells and in spores (Fig. 3). Their mitochondrial element levels were similar, except for $\mathrm{Cl}$ which was enhanced in spores $(18.1 \pm 2 \mathrm{vs} 4.3 \pm 1 \mathrm{mmol} / \mathrm{kg}$ dry weight in spores and prespores). However, in prestalk amoebae mitochondria were not unambiguously identified. Structures with a size and mass density typical of mitochondria were present. Yet, their X-ray spectra had a high $\mathrm{P} / \mathrm{S}$ ratio and a high $\mathrm{Mg}$ content and, therefore, were assigned to MDGs (see Fig. 6 and below). In freeze-substituted slugs viewed with transmission electron microscopy mitochondria were detected in both prestalk and prespore cells (not shown). Prestalk cell mitochondria might be in a different metabolic state reflected by an altered elemental composition. Altered respiratory activity was postulated by Matsuyama and Maeda [26], who incubated slugs with rhodamine 123 and found fluorescence in the prespore region. Under our experimental conditions rhodamine 123 stained cells in the prestalk zone of slugs only (Fig. 4). In prespore cells the presence of a multidrug resistance transporter was reported [29]; such proteins have proven to be a problem for labelling mitochondria with rhodamine 123 [30]. In summary, these results point to a functional difference between mitochondria of the two cell types. If indeed a fraction of the X-ray spectra assigned to MDGs had been derived from mitochondria, then prestalk cell mitochondria would have an elemental composition substantially distinct from those of prespore amoebae.

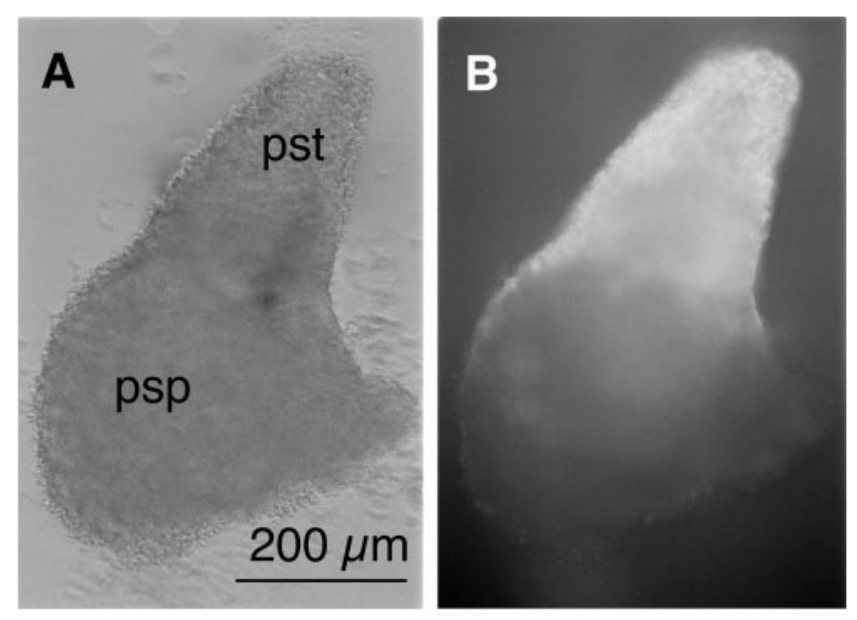

Fig. 4 Rhodamine 123 stains the prestalk zone of pseudoplasmodia. (A) bright field, (B) fluorescence micrograph of one slug. Prestalk (pst) but not prespore (psp) cells fluoresced.

In mass dense granules Ca was present at high levels. Yet, individual granules showed striking differences in their Ca content. Therefore, the population was divided in two classes. Granules with high amounts of $\mathrm{Ca}$ were termed Ca-MDGs. Ca-MDGs and MDGs with a Ca content less than $20 \mathrm{mmol} / \mathrm{kg}$ dry weight had high amounts of $\mathrm{Mg}$ and $\mathrm{P}$ (Tables $1 \&$ 2). The distribution of $\mathrm{Ca}$ in MDGs of prestalk and prespore cells is shown in Figure 5. In prestalk cells a greater portion of granules were CaMDGs, whereas in prespore cells the relative fraction of MDGs and Ca-MDGs was similar. Comparison of the size distribution of the MDGs in prespore and prestalk cells showed that the majority of the MDGs and also of the Ca-MDGs in the former were rather small (77 and 72\% were less than $350 \mathrm{~nm}$ ). By contrast, in prestalk cells small MDGs and Ca-MDGs were also present (35 and $34 \%$ were less than $350 \mathrm{~nm}$ ), yet a substantial fraction had a size in the range of that of mitochondria $(31 \%$ of Ca-MDGs were larger than $500 \mathrm{~nm}$ as compared to $3 \%$ of prespore Ca-MDGs). The element composition of the granules (Fig. 6) differed from that of mitochondria, with a higher $\mathrm{P} / \mathrm{S}$ ratio and a higher amount of $\mathrm{Mg}$ and $\mathrm{Ca}$. Only stalk cell granules had a lower $\mathrm{P} / \mathrm{S}$ ratio of $6-7$. Comparison of Ca-MDGs of prestalk and prespore cells showed a significantly higher dry weight amount of Ca in the latter. Calculation of the water content (Table 3) and of wet-weight $\mathrm{Ca}^{2+}$ in Ca-MDGs resulted in an average of $202 \pm 67 \mathrm{mM}$ in prespore versus $39 \pm 5 \mathrm{mM}$ in prestalk amoebae. Taking into account the volume of the Ca-MDGs $(3 \times$ higher in prestalk than prespore cells assuming a spherical volume) and their relative abundance per section and cell $(1.2 \times$ more in prestalk compared to prespore cells) the ratio of total Ca in Ca-MDGs of prespore to prestalk amoebae was determined to be 


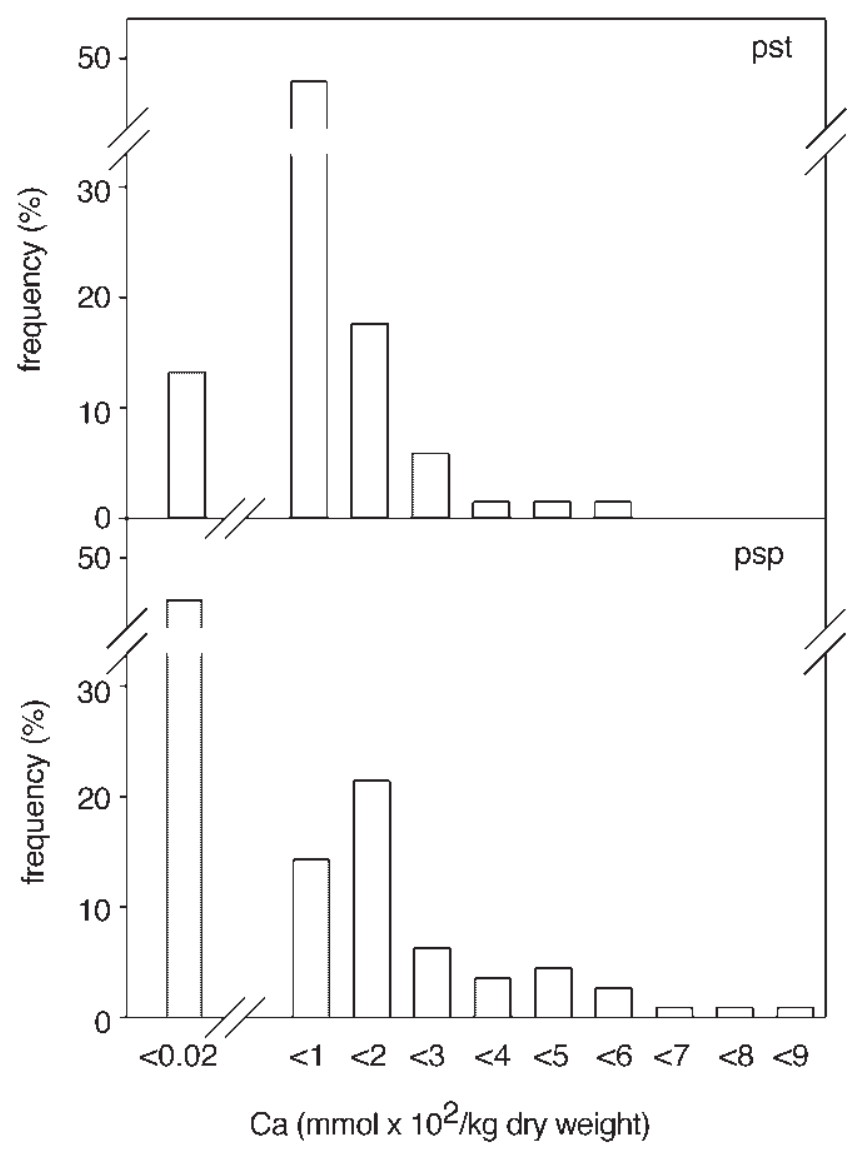

Fig. 5 Distribution of $\mathrm{Ca}$ in prestalk (pst) and prespore (psp) MDGs. Granules were classified according to their Ca content. Ca levels were plotted against the relative frequency. Few prestalk cell granules had a Ca content of $<20 \mathrm{mmol} / \mathrm{kg}$ dry weight; most of the Ca-rich granules had $20-100 \mathrm{mmol} \mathrm{Ca} / \mathrm{kg}$ dry weight. Roughly $50 \%$ of prespore granules were in the range of $<20 \mathrm{mmol} \mathrm{Ca} / \mathrm{kg}$ dry weight; Ca-rich granules had up to $900 \mathrm{mmol} \mathrm{Ca} / \mathrm{kg}$ dry weight.

1.4. These numbers were calculated using only those granules whose mass density was in a range that is linearly correlated with dark field intensity [25]. In prespore cells 16 Ca-MDGs were excluded from statistical analysis due to very high mass density (relative dark field intensity $\mathrm{I}_{\mathrm{o}} / \mathrm{I}_{\mathrm{f}}>3.5$ ), whereas only 1 Ca-MDG from prestalk cells was excluded. Therefore, in prespore Ca-MDGs, the actual average wet-weight $\mathrm{Ca}^{2+}$ is even higher.

In spores, MDGs and Ca-MDGs were also found. MDGs had a higher content of $\mathrm{Mg}$ and $\mathrm{P}$ than the corresponding class of granules in prespore cells (Fig. 6; Tables 1 \& 2). In Ca-MDGs the dry weight amount of Ca was significantly lower than in prespore amoebae. In stalk cells, small particulate structures of high mass density were present that differed in size from that of the granules of the other cell types. Ca-MDGs contained higher amounts of $\mathrm{Ca}$ and also of $\mathrm{S}$ and $\mathrm{Cl}$ compared to Ca-MDGs in prestalk cells.

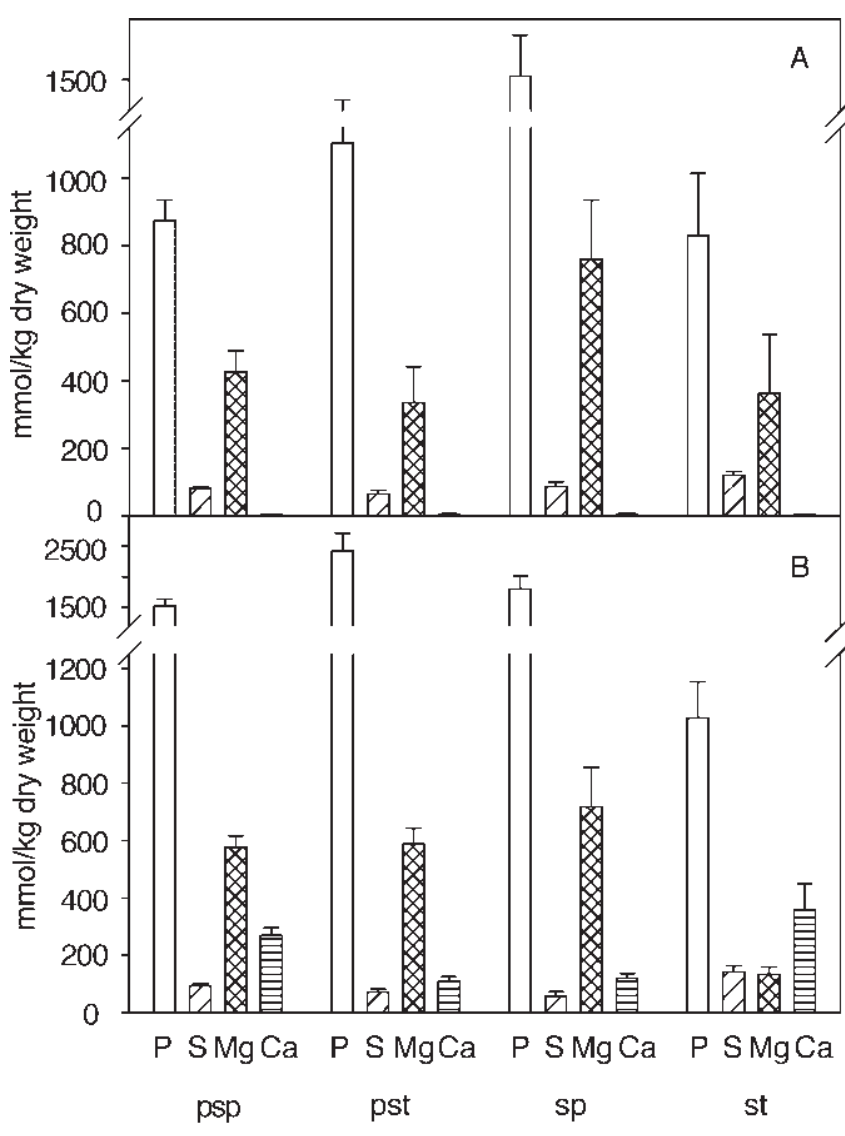

Fig. 6 Element contents in MDGs (A) and in Ca-MDGs (B) of different cell types. The amounts of $\mathrm{P}, \mathrm{S}, \mathrm{Mg}$ and $\mathrm{Ca}(\mathrm{mmol} / \mathrm{kg}$ dry weight, mean \pm SEM) in granules of prespore (psp), prestalk (pst), spores (sp) and stalk (st) cells are plotted. The $\mathrm{P} / \mathrm{S}$ ratio and $\mathrm{Ca}$ and/or Mg levels were higher than in mitochondria.

Amoebae had a high capacity to sequester $\mathrm{Ca}^{2+}$. When cells differentiated to the slug stage in nominally $\mathrm{Ca}^{2+}$-free buffer, the Ca content of MDGs was 10-20× lower than in the presence of external $\mathrm{Ca}^{2+}$. The average amount of $\mathrm{Ca}$ in the granules was $21 \pm 5 \mathrm{mmol} / \mathrm{kg}$ dry weight (mean \pm SEM; $n=9$ ) in prespore and $5 \pm 2.45 \mathrm{mmol} / \mathrm{kg}$ dry weight (mean \pm SEM; $n=17$ ) in prestalk cells. Calculation of wetweight $\mathrm{Ca}^{2+}$ in the MDGs yielded a value of $2.5 \pm 0.7 \mathrm{mM}$ in prespore and of $2.7 \pm 0.4 \mathrm{mM}$ in prestalk amoebae.

\section{Comparison of the element content of Ca-MDGs throughout development}

The element content of Ca-MDGs at various stages of differentiation is plotted in Figure 7. Dry-weight levels of $\mathrm{Ca}, \mathrm{Mg}$ and $\mathrm{P}$ increased until aggregate formation. By contrast, the $\mathrm{K}$ content peaked at aggregation competence and was strongly reduced in the aggregate stage. Mean values of elements during early development were taken from [4]. In slugs dry weight levels of all elements 

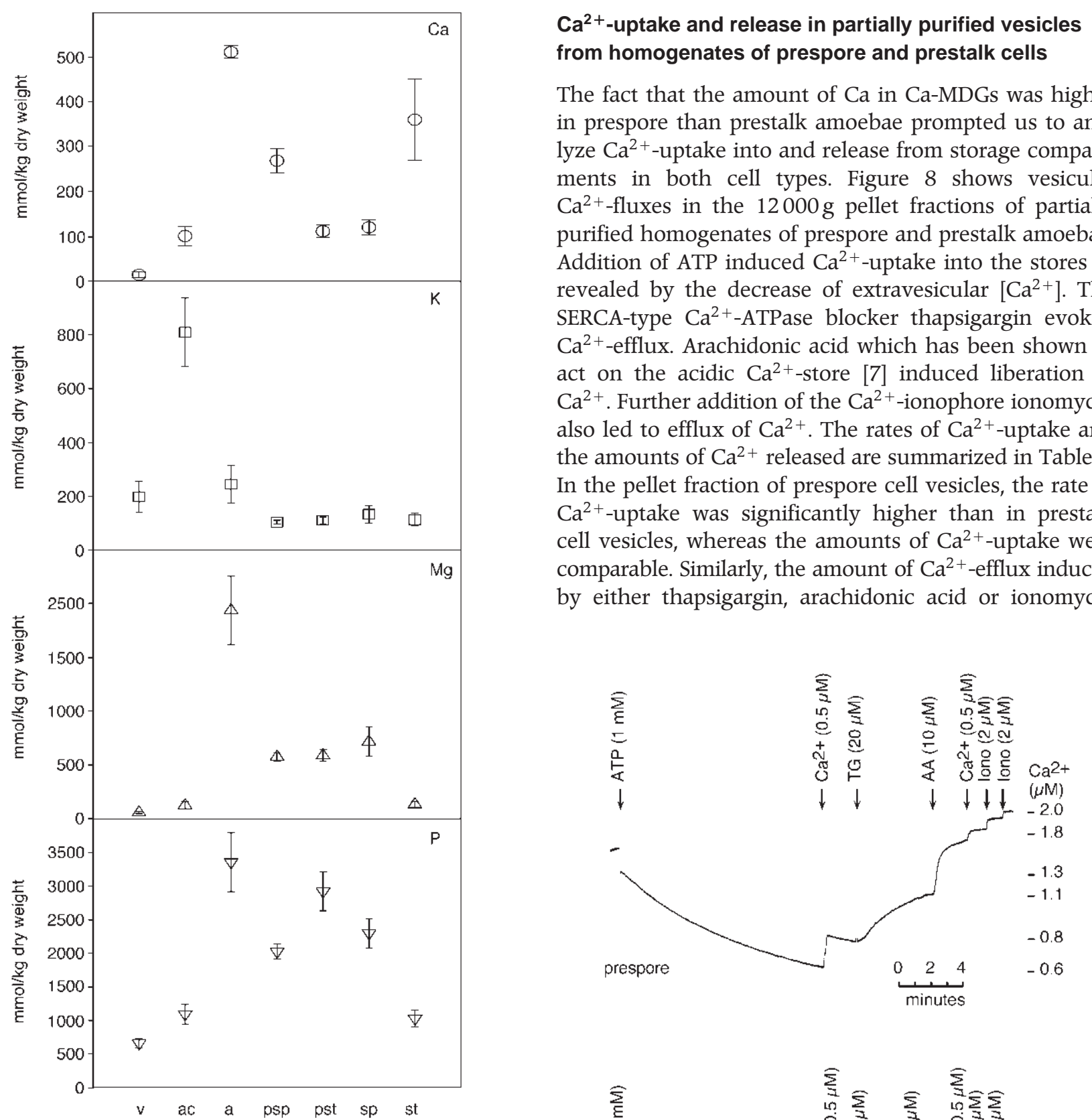

Fig. 7 Element content of Ca-MDGs during differentiation of $D$. discoideum. The developmental stage was plotted versus the amounts of $\mathrm{Ca}, \mathrm{K}, \mathrm{Mg}$ and $\mathrm{P}$ (mmol/kg dry weight; mean $\pm \mathrm{SEM}$ ). v: vegetative, ac: aggregation competent, a: aggregated cells (values were taken from [4]). psp and pst: prespore and prestalk cells, sp: spores and st: stalk cells.

decreased. Ca was significantly higher in prespore than prestalk cells; the reverse was found for P. In spores less Ca was present than in prespore cells. The content of the other elements remained unchanged. In mass dense structures of stalk cells the Ca level was high, whereas $\mathrm{Mg}$ and $\mathrm{P}$ were significantly lower as compared to prestalk cells.
The fact that the amount of Ca in Ca-MDGs was higher in prespore than prestalk amoebae prompted us to analyze $\mathrm{Ca}^{2+}$-uptake into and release from storage compartments in both cell types. Figure 8 shows vesicular $\mathrm{Ca}^{2+}$-fluxes in the $12000 \mathrm{~g}$ pellet fractions of partially purified homogenates of prespore and prestalk amoebae. Addition of ATP induced $\mathrm{Ca}^{2+}$-uptake into the stores as revealed by the decrease of extravesicular $\left[\mathrm{Ca}^{2+}\right]$. The SERCA-type $\mathrm{Ca}^{2+}$-ATPase blocker thapsigargin evoked $\mathrm{Ca}^{2+}$-efflux. Arachidonic acid which has been shown to act on the acidic $\mathrm{Ca}^{2+}$-store [7] induced liberation of $\mathrm{Ca}^{2+}$. Further addition of the $\mathrm{Ca}^{2+}$-ionophore ionomycin also led to efflux of $\mathrm{Ca}^{2+}$. The rates of $\mathrm{Ca}^{2+}$-uptake and the amounts of $\mathrm{Ca}^{2+}$ released are summarized in Table 4 . In the pellet fraction of prespore cell vesicles, the rate of $\mathrm{Ca}^{2+}$-uptake was significantly higher than in prestalk cell vesicles, whereas the amounts of $\mathrm{Ca}^{2+}$-uptake were comparable. Similarly, the amount of $\mathrm{Ca}^{2+}$-efflux induced by either thapsigargin, arachidonic acid or ionomycin
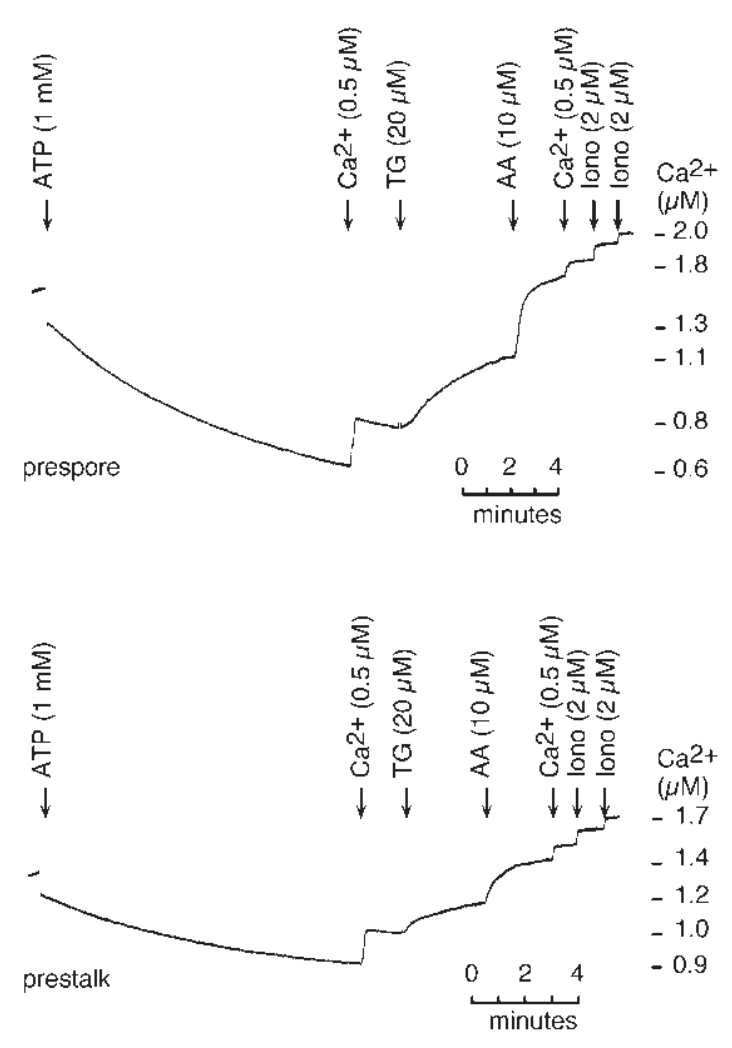

Fig. $8 \mathrm{Ca}^{2+}$-uptake and release from microsomal fractions of prespore and prestalk cell homogenates. Uptake into the pellet fractions is shown. Bars on the right hand indicate extravesicular $\left[\mathrm{Ca}^{2+}\right]$. Thapsigargin (TG), arachidonic acid (AA) and ionomycin (lono) led to $\mathrm{Ca}^{2+}$-release. One of 4 determinations of two independent experiments each is shown. 
Table $4 \mathrm{Ca}^{2+}$ uptake into and release from storage compartments of prespore and prestalk cells

\begin{tabular}{|c|c|c|c|c|c|c|}
\hline \multirow{2}{*}{$\begin{array}{l}\text { Cell type } \\
\text { Fraction }\end{array}$} & \multicolumn{2}{|c|}{$\mathrm{Ca}^{2+}$ uptake } & \multicolumn{4}{|c|}{$\mathrm{Ca}^{2+}$ release } \\
\hline & $\begin{array}{c}\text { Rate } \\
\text { nmol/min*mg }\end{array}$ & $\begin{array}{c}\text { Total } \\
\mathrm{nmol} / \mathrm{mg}\end{array}$ & $\begin{array}{c}\text { Thapsigargin } \\
(20 \mu \mathrm{M}) \\
\mathrm{nmol} / \mathrm{mg}\end{array}$ & $\begin{array}{c}\text { Arachidonic } \\
\text { acid }(10 \mu \mathrm{M}) \\
\mathrm{nmol} / \mathrm{mg}\end{array}$ & $\begin{array}{c}\text { Ionomycin } \\
(5 \mu \mathrm{M}) \\
\mathrm{nmol} / \mathrm{mg}\end{array}$ & $\begin{array}{c}\text { Total } \\
\mathrm{nmol} / 10^{8} \text { cells }\end{array}$ \\
\hline $\begin{array}{l}\text { Prespore } \\
\text { Pellet } \\
\text { Supernatant } \\
\text { Ratio S/P }\end{array}$ & $\begin{array}{c}4.7 \pm 0.6(4) \\
0.07 \pm 0.05(2)\end{array}$ & $\begin{array}{r}17 \pm 0.16(6) \\
0.2 \pm 0.13(2)\end{array}$ & $12 \pm 1.6(4)$ & $15.8 \pm 0.2(6)$ & $\begin{array}{r}15.2 \pm 0.2(3) \\
2.8 \pm 1.5(2)\end{array}$ & $\begin{array}{l}13 \pm 1.2(6) \\
7.7 \pm 0.8(2) \\
0.6 \pm 0.12\end{array}$ \\
\hline $\begin{array}{l}\text { Prestalk } \\
\text { Pellet } \\
\text { Supernatant } \\
\text { Ratio S/P }\end{array}$ & $\begin{array}{r}3.4 \pm 0.13(4) \\
0.02 \pm 0.02(2)\end{array}$ & $\begin{array}{l}13.3 \pm 0.7(6) \\
0.05 \pm 0.05(2)\end{array}$ & $8.3 \pm 1.5(4)$ & $12.9 \pm 0.9(5)$ & $\begin{array}{r}14.2 \pm 0.6(3) \\
7.9 \pm 1.9(2)\end{array}$ & $\begin{array}{r}9.9 \pm 0.9(6) \\
16.5 \pm 1.6(2) \\
1.7 \pm 0.27\end{array}$ \\
\hline
\end{tabular}

was in the same range in the pellet fractions from both prespore and prestalk cell homogenates. The storage compartments in the pellet fractions of both cell types contained $\mathrm{Ca}^{2+}$ already at the start of the experiment as the average sum of $\mathrm{Ca}^{2+}$ released by the above agents $(41.4 \pm 3.8$ and $35.1 \pm 3.6 \mathrm{nmol} / \mathrm{mg}$ protein in prespore and prestalk homogenates) was 2.4 and 2.6 times higher than the amount of ATP-induced $\mathrm{Ca}^{2+}$-uptake.

In the supernatant of homogenates from both cell types $\mathrm{Ca}^{2+}$-uptake activated by ATP was negligible. $\mathrm{Ca}^{2+}$-efflux occurred after addition of ionomycin. Thapsigargin also induced efflux of $\mathrm{Ca}^{2+}(0.22$ and $0.25 \mathrm{nmol} / \mathrm{mg}$ protein in prespore and prestalk cell homogenates) as well as arachidonic acid (1.22 and $0.79 \mathrm{nmol} / \mathrm{mg}$ protein). The amount of $\mathrm{Ca}^{2+}$ stored in the vesicles of supernatant fractions was high even in the absence of significant uptake. This was particularly evident in prestalk cell homogenates: $1.7 \times$ more $\mathrm{Ca}^{2+}$ was liberated in the supernatant than in the pellet fraction. By contrast, in prespore cell homogenates the ratio of $\mathrm{Ca}^{2+}$ released from supernatant to pellet fraction was 0.6 (Table 4). As the sum of $\mathrm{Ca}^{2+}$-efflux from pellet and supernatant fraction was similar in the two cell types $\left(11.7 \pm 1.2 \mathrm{nmol} / 10^{8}\right.$ cells in prespore cell homogenates vs. $11.6 \pm 1.3 \mathrm{nmol} / 10^{8}$ cells in prestalk cell homogenates), these different ratios point to an altered distribution of storage compartments in prespore and prestalk amoebae.

\section{DIsCussion}

In D. discoideum cells high amounts of Ca were found in MDGs in prestalk as well as in prespore and in spore cells. Ca was colocalized with $\mathrm{Mg}$ and P. Similar organelles were found in other cell systems such as
Amoeba proteus [18], eukaryotic parasites [28] or yeast [31]. In Amoeba, the organelles are located at the uropod [18] which displays elevated $\left[\mathrm{Ca}^{2+}\right]_{\mathrm{i}}$ during migration [32]. In parasites, the organelles might be required during distinct phases of the life cycle; changes in the $\left[\mathrm{Ca}^{2+}\right]-$ homeostasis were reported to be essential for host invasion [33].

What are the function(s) of Ca-rich MDGs in Dictyostelium? Ca accumulation until aggregation might serve to provide $\mathrm{Ca}$ for regulation once the slug has formed. The slime sheath covering the slug protects the cells from their environment. Thus they remain independent of external $\left[\mathrm{Ca}^{2+}\right]$, which might vary in the natural habitat. $\left[\mathrm{Ca}^{2+}\right]_{\mathrm{i}}$-changes required for development can be mediated by redistribution of stored $\mathrm{Ca}^{2+}$; influx of $\mathrm{Ca}^{2+}$ might no longer be necessary. In spores, Ca-MDGs could be involved in germination processes which are $\mathrm{Ca}^{2+}$-dependent [34].

In stalk cells Ca-rich granules could represent $\mathrm{Ca}^{2+}$-salt precipitates. Cytosolic element levels were high, probably due to redistribution from disintegrating organelles. Alternatively, the mass dense structures could be mitochondrial matrix granules known in several other cells [35]. Their function is not clarified. In damaged muscle cells they were shown to accumulate $\mathrm{Ca}$ [36]. In osteoblasts mitochondria contain high levels of $\mathrm{Ca}$ and $\mathrm{P}$ in matrix granules [37]. Degenerating osteoblasts release mineral crystals leading to bone calcification. Similarly, $D$. discoideum prestalk cells will finally die and give rise to the stalk structure. If prestalk cell mitochondria had $\mathrm{Ca}$ (and $\mathrm{Mg}$ ) and $\mathrm{P}$ containing matrix granules analogous to osteoblasts, their X-ray spectra would differ from those recorded of prespore cell mitochondria. In prestalk amoebae no X-ray spectra similar to those of prespore or 
spore mitochondria were measured. Structures comparable to mitochondria were asssigned to MDGs due to their high $\mathrm{P}$ and $\mathrm{Ca} / \mathrm{Mg}$ content. Analysis of the size distribution revealed that most of the prespore MDGs and Ca-MDGs were small. In prestalk cells small MDGs and Ca-MDGs were also present; however, a substantial fraction had a size in the range of that of mitochondria. From these results we assume that prestalk cell mitochondria have an element content similar to mass dense granules; it is clearly different from those of prespore amoebae which would support the notion of functional differences of mitochondria between the cell types.

The presence of Ca-MDGs in prestalk and in prespore cells provides an explanation for results of studies on the role of $\mathrm{Ca}^{2+}$ in cell-type-specific gene expression. CaMDGs could be involved in the generation of $\mathrm{Ca}^{2+}$-fluxes necessary for prestalk as well as prespore differentiation. Depletion of cellular $\mathrm{Ca}^{2+}$ by incubation with $\mathrm{Ca}^{2+}$ chelating agents inhibited prestalk and prespore gene expression to the same extent $[16,17]$. Such treatment should reduce both, $\left[\mathrm{Ca}^{2+}\right]_{i}$ and sequestered $\mathrm{Ca}^{2+}$. Inhibition of cAMP-induced $\mathrm{Ca}^{2+}$-fluxes by $\mathrm{Ca}^{2+}$-antagonists reduced prespore mRNA accumulation [15]. These data are in conflict with the view that $\mathrm{Ca}^{2+}$ is required predominantly for prestalk and stalk cell differentiation [14]. This view results from studies showing, e.g. induction of prestalk gene transcripts by incubation of cells with $\mathrm{Ca}^{2+}$-ATPase blockers which elevate $\left[\mathrm{Ca}^{2+}\right]_{\mathrm{i}}[13]$. Prestalk cells were reported to have higher levels of total and sequestered $\mathrm{Ca}^{2+}$, and of basal free cytosolic $\left[\mathrm{Ca}^{2+}\right]$ than prespore amoebae [10-12].

We found that in the cytosol the level of total aqueous $\mathrm{Ca}^{2+}$ was similar in the two cell types. By contrast, free cytosolic $\left[\mathrm{Ca}^{2+}\right]$ of amoebae in the prestalk region of pseudoplasmodia was higher than that of amoebae in the prespore zone. This result is consistent with data from earlier studies performed both with the fluorescent $\left[\mathrm{Ca}^{2+}\right]$-indicator Fura-2 [38] and the luminescent $\left[\mathrm{Ca}^{2+}\right]-$ indicator protein aequorin $[12,13,39]$. We, therefore, conclude that the cytosol of prespore and of prestalk amoebae must have distinct, characteristic properties in order to generate a difference in free cytosolic $\left[\mathrm{Ca}^{2+}\right]$ at comparable levels of total aqueous $\mathrm{Ca}^{2+}$. Either different amounts or types of $\mathrm{Ca}^{2+}$-binding proteins might be present in prespore and prestalk cells leading to altered buffering of $\mathrm{Ca}^{2+}$ and thus free cytosolic $\left[\mathrm{Ca}^{2+}\right]$. With respect to the amounts of sequestered $\mathrm{Ca}$, the difference between the above results and those of our study could be due to the techniques applied for analysis. Experiments with the dye CTC led to the conclusion that $\mathrm{Ca}^{2+}$ was sequestered selectively in acidic vesicles in prestalk but not in prespore cells [11]. Yet, CTC-fluorescence depends on $\mathrm{pH}$ : it is $30 \times$ lower at $\mathrm{pH} 6.5$ than at $\mathrm{pH} 7.5$ [40], thus impeding detection of acidic stores. As CTC cannot label all types of $\mathrm{Ca}^{2+}$-stores, the above study provides no information on storage compartments in prespore cells. A ${ }^{45} \mathrm{Ca}^{2+}$-autoradiographic study reported higher total levels of $\mathrm{Ca}^{2+}$ in prestalk cells of chemically fixed slugs [10]. This method can induce gross redistribution of soluble elements within cells and with the external medium [18]; elements will become trapped at high-affinity binding sites. Cryofixation applied in our study preserves element localization $[20,21]$. The autoradiography data [10] could also be interpreted by high-affinity binding sites present in prestalk cells and occupied artefactually or physiologically in a compartment with a slow $\mathrm{Ca}^{2+}$ turnover rate. Low affinity and rapidly exchanging $\mathrm{Ca}^{2+}$ stores should escape detection with this technique.

Indeed, our results obtained from fractionated cells argue for the existence of such a store in prespore cells. Vesicular $\mathrm{Ca}^{2+}$-uptake proceeded at a higher rate in the pellet fraction derived from prespore than from prestalk cells. In the supernatant fractions from both cell types $\mathrm{Ca}^{2+}$-uptake was negligible. This is in contrast with results from studies using homogenates of cells at early differentiation stages where ATP-evoked $\mathrm{Ca}^{2+}$-uptake in the pellet and supernatant fraction was equal [41]. In addition, the pellet was shown to contain a thapsigarginand $\mathrm{IP}_{3}$-sensitive store [41], whereas in the supernatant fatty acid-sensitive storage compartments were present [7]. In the supernatant fractions from both prespore and prestalk cells the addition of ionomycin, but not arachidonic acid, led to substantial $\mathrm{Ca}^{2+}$-release which points to a distinct change of responsiveness in the course of differentiation. More $\mathrm{Ca}^{2+}$ was releasable from the supernatant than from the pellet fraction of prestalk cell homogenates, indicating that in these cells a greater portion of $\mathrm{Ca}^{2+}$-stores is comprised of a high-affinity compartment which exchanges $\mathrm{Ca}^{2+}$ at a low rate. In summary, results from measurements of vesicles in suspension lead to two conclusions. In both cell types (at least) two different $\mathrm{Ca}^{2+}$-stores exist which differ in their filling state, their rate and amount of ATP-induced $\mathrm{Ca}^{2+}$ uptake and their sensitivity towards agonists. The $\mathrm{Ca}^{2+}$ sequestration and release characteristics of both stores are developmentally regulated. Whether one particular type or a mixture of the stores represents the MDGs is at present unclear.

The capacity of MDGs to sequester $\mathrm{Ca}^{2+}$ was high. Slug formation in the presence or absence of $\mathrm{Ca}^{2+}$ affected $\mathrm{Ca}$ levels in MDGs by a factor of 10-20. Independent of external $\left[\mathrm{Ca}^{2+}\right]$ more $\mathrm{Ca}$, related to dry weight, was present in prespore cells. We conclude that the capacity to accumulate $\mathrm{Ca}^{2+}$ in MDGs is greater in prespore than prestalk cells. This should reflect different composition of the stores and should affect $\left[\mathrm{Ca}^{2+}\right]_{\mathrm{i}} \mathrm{P}$ and $\mathrm{S}$ were unequally distributed in Ca-MDGs of prestalk and prespore cells which argues for qualitative differences in 
store composition. S mainly indicates S-containing amino acids. In prespore cell Ca-MDGs the $\mathrm{S}$ content was high, pointing to either increased protein concentrations as compared to prestalk cells or to the presence of proteins rich in cysteine or methionine. The level of $\mathrm{P}$ which might serve to bind Ca was lower in prespore cell Ca-MDGs.

At present, it is unclear how $\mathrm{Ca}^{2+}$ is stored in the granules. $\mathrm{Ca}^{2+}$ could be bound to protein(s) and polyphosphates or highly phosphorylated sugar molecules. In D. discoideum various inositol phosphates are present whose contents increase during development [42-45]. Electron beam irradiation caused 'bubbling' of MDGs, a phenomenon characteristic for sugar molecules [28]. In Trypanosoma cruzi a significant portion of the matrix of acidocalcisomes is comprised of sugar molecules [28]. The element composition of acidocalcisomes is similar to that of Ca-MDGs in Dictyostelium. Acidocalcisomes display similar $\mathrm{Ca}^{2+}$-uptake mechanisms as acidic $\mathrm{Ca}^{2+}$ stores in Dictyostelium $[6,9,46,47]$. From these parallel observations we assume that Ca-MDGs of Dictyostelium represent one type of acidic $\mathrm{Ca}^{2+}$-store. In Trypanosoma and Dictyostelium, $\mathrm{Mg}$ was colocalized with $\mathrm{Ca}$ in mass dense structures. In addition, MDGs containing Mg with high $\mathrm{P}$, but low $\mathrm{Ca}$, were present in all cell types analyzed. The distribution of these MDGs was different in prespore and prestalk cells; their function is unclear. $\mathrm{Mg}^{2+}$-sequestration and agonist-induced $\mathrm{Mg}^{2+}$-fluxes were shown in other cells such as sublingual mucous acini [48] or bee photoreceptors [49]. A $\mathrm{Mg}^{2+} / \mathrm{H}^{+}-$ exchanger located at the acidic vacuole membrane of Arabidopsis was cloned and characterized [50]; whether such a protein exists in Dictyostelium is unknown. In our study $\mathrm{Mg}$ was not a component of the medium, so sequestration from other compartments is probable. Indeed, cytosolic $\mathrm{Mg}$ decreased from the vegetative to the aggregated stage of development [4]. This should influence metabolism by affecting $\mathrm{Mg}^{2+}$-dependent enzymes. Further biochemical and pharmacological characterization of the different types of stores and of the mitochondria in predifferentiated cells will allow to gain insight in the role of these compartments in the patterning processes in Dictyostelium.

\section{ACKNOWLEDGEMENTS}

We wish to thank S. Dongard for excellent technical assistance. We are grateful to D. Malchow, R. Schaloske and R. Mutzel for discussions and critical reading of the manuscript and to the Deutsche Forschungsgemeinschaft for support.

\section{REFERENCES}

1. Parent C, Devreotes P. A cell's sense of direction. Science 1999; 284: $765-770$.
2. Sonnemann J, Knoll G, Schlatterer C. cAMP-induced changes in the cytosolic free $\mathrm{Ca}^{2+}$ concentration in Dictyostelium discoideum are light sensitive. Cell Calcium 1997; 22: 65-74.

3. Unterweger N, Schlatterer C. Introduction of calcium buffers into the cytosol of Dictyostelium discoideum amoebae alters cell morphology and inhibits chemotaxis. Cell Calcium 1995; 17: 97-110.

4. Schlatterer C, Buravkov S, Zierold K, Knoll G. Calciumsequestering organelles of Dictyostelium discoideum: changes in element content during early development as measured by electron probe X-ray microanalysis. Cell Calcium 1994; 16: 101-111.

5. Flaadt H, Jaworski E, Malchow D. Evidence for two intracellular calcium pools in Dictyostelium - the cAMP-induced calcium influx is directed into a NBD-Cl- and 2,5-di-(tert-butyl)-1,4hydroquinone-sensitive pool. J Cell Sci 1993; 105: 1131-1135.

6. Rooney EK, Gross JD. ATP-driven $\mathrm{Ca}^{2+} / \mathrm{H}^{+}$antiport in acid vesicles from Dictyostelium. Proc Natl Acad Sci USA 1992; 89: 8025-8029.

7. Schaloske R, Sonnemann J, Malchow D, Schlatterer C. Fatty acids induce release of $\mathrm{Ca}^{2+}$ from acidosomal stores and activate capacitative $\mathrm{Ca}^{2+}$-entry in Dictyostelium discoideum. Biochem J 1998; 332: 541-548.

8. Lu H-G, Zhong L, De Souza W, Benchimol M, Moreno S, Docampo R. $\mathrm{Ca}^{2+}$ content and expression of an acidocalcisomal calcium pump are elevated in intracellular forms of Trypanosoma cruzi. Mol Cell Biol 1998; 18: 2309-2323.

9. Scott DA, Docampo R. Two types of $\mathrm{H}^{+}$-ATPase are involved in the acidification of internal compartments in Trypanosoma cruzi. Biochem J 1998; 331: 583-589.

10. Maeda Y, Maeda M. The calcium content of the cellular slime mold, Dictyostelium discoideum, during development and differentiation. Exp Cell Res 1973; 82: 125-130.

11. Tirlapur UK, Gross J, Nanjundiah V. Spatial variation of sequestered calcium in the multicellular stage of Dictyostelium discoideum as assayed by chlortetracycline fluorescence. Differentiation 1991; 48: 137-146.

12. Cubitt AB, Firtel RA, Fischer G, Jaffe LF, Miller AL. Patterns of free calcium in multicellular stages of Dictyostelium expressing jellyfish apoaequorin. Development 1995; 121: 2291-2301.

13. Schaap P, Nebl T, Fisher PR. A slow sustained increase in cytosolic $\mathrm{Ca}^{2}+$ levels mediates stalk gene induction by differentiation of inducing factor in Dictyostelium. EMBO J 1996; 15: 5177-5183.

14. Gross JD. Developmental decisions in Dictyostelium discoideum. Microbiol Rev 1994; 58: 330-351.

15. Blumberg DD, Comer JF, Walton EM. Ca ${ }^{++}$antagonists distinguish different requirements for cAMP-mediated gene expression in the cellular slime mold, Dictyostelium discoideum. Differentiation 1989; 41: 14-21.

16. Pinter K, Gross J. Calcium and cell-type-specific gene expression in Dictyostelium. Differentiation 1995; 59: 201-206.

17. Cubitt AB, Reddy I, Lee S, McNally JG, Firtel RA. Coexpression of a constitutively active plasma membrane calcium pump with GFP identifies roles for intracellular calcium in controlling cell sorting during morphogenesis in Dictyostelium. Dev Biol 1998; 196: $77-94$.

18. Zierold K, Schäfer D. Preparation of cultured and isolated cells for X-ray microanalysis. Scanning Microsc 1988; 2: 1775-1790.

19. Blinks JR, Wier WG, Hess P, Prendergast FG. Measurement of $\mathrm{Ca}^{2+}$ concentrations in living cells. Prog Biophys molec Biol 1982; 40: $1-114$

20. Somlyo AP, Somlyo AV, Bond M, Broderick R, Goldman YE, Shuman H, Walker JW, Trentham DR. Calcium and magnesium movements in cells and the role of inositol trisphosphate in 
muscle. In: Mandel L, Eaton D (eds). Cell Calcium and the Control of Membrane Transport. New York, The Rockefeller University Press, 1987; 77-92.

21. Zierold K. Cryofixation methods for ion localization in cells by electron probe microanalysis - a review. J Microsc Oxford 1991; 161: $357-366$.

22. Ryan K, Knoll G. Time-resolved cryofixation methods for the study of dynamic cellular events by electron microscopy: A review. Scanning Microsc 1994; 8: 259-288.

23. Moor $\mathrm{H}$. Theory and practice of high pressure freezing. In: Steinbrecht RA, Zierold K (eds). Cryotechniques in Biological Electron Microscopy. Berlin, Heidelberg, New York, Springer Verlag, 1987; 175-191.

24. Zierold K. X-ray microanalysis of freeze-dried and frozenhydrated cryosections. J Electr Microsc Tech 1988; 9: 65-82.

25. Zierold $\mathrm{K}$. The determination of wet weight concentrations of elements in freeze-dried cryosections from biological cells. Scan Electron Microsc 1986; 2: 713-724.

26. Matsuyama SI, Maeda Y. Involvement of cyanide-resistant respiration in cell-type proportioning during Dictyostelium development. Dev Biol 1995; 172: 182-191.

27. Somlyo AP. Cell calcium measurements with electron probe and electron energy loss analysis. Cell Calcium 1985; 6: 197-212.

28. Scott DA, Docampo R, Dvorak JA, Shi S, Leapman RD. In situ compositional analysis of acidocalcisomes in Trypanosoma cruzi. J Biol Chem 1997; 272: 28020-28029.

29. Good JR, Kuspa A. Evidence that a cell-type-specific efflux pump regulates cell differentiation in Dictyostelium. Dev Biol 2000; 220: $53-61$.

30. Bernardi P, Scorrano L, Colonna R, Petronilli V, Di Lisa F. Mitochondria and cell death. Mechanistic aspects and methodological issues. Eur J Biochem 1999; 264: 687-701.

31. Zierold K. Electron probe microanalysis of cryosections from cell suspensions. Methods Microbiol 1988; 20: 91-111.

32. Gollnick F, Meyer R, Stockem W. Visualization and measurement of calcium transients in Amoeba proteus by Fura-2 fluorescence. Eur J Cell Biol 1991; 55: 262-271.

33. Pezzella N, Bouchot A, Bonhomme A, Pingret L, Klein C, Burlet $\mathrm{H}$, Balossier G, Bonhomme P, Pinon J. Involvement of calcium and calmodulin in Toxoplasma gondii tachyzoite invasion. Eur J Cell Biol 1997; 74: 92-101.

34. Lydan $\mathrm{M}$, Cotter $\mathrm{D}$. The role of $\mathrm{Ca}^{2+}$ during spore germination in Dictyostelium: Autoactivation is mediated by the mobilization of $\mathrm{Ca}^{2+}$ while amoebal emergence requires entry of external $\mathrm{Ca}^{2+}$. J Cell Sci 1995; 108: 1921-1930.

35. Jacob W, Bakker A, Hertsens R, Biermans W. Mitochondrial matrix granules: their behaviour during changing metabolic situations and their relationship to contact sites between inner and outer mitochondrial membranes. Microsc Res Tech 1994; 27: $307-318$.

36. Somlyo AP, Somlyo AV, Shuman H, Stewart M. Electron probe analysis of muscle and X-ray mapping of biological specimens with a field emission gun. Scan Electron Microsc 1979; 2: 711-722

37. Bordat C, Bouet O, Cournot G. Calcium distribution in highpressure frozen bone cells by electron energy loss spectroscopy and electron spectroscopic imaging. Histochem Cell Biol 1998; 109: 167-174.

38. Yumura S, Furuya K, Takeuchi I. Intracellular free calcium responses during chemotaxis of Dictyostelium cells. J Cell Sci 1996; 109: 2673-2678.

39. Saran S, Nahao H, Tasaka M, Iida H, Tsuji FI, Nanjundiah V, Takeuchi I. Intracellular free calcium level and its response to cAMP stimulation in developing Dictyostelium cells transformed with jellyfish apoaequorin. FEBS Lett 1994; 337: 43-47.

40. Tang S, Beeler T. Optical response of the indicator chlortetracycline to membrane potential. Cell Calcium 1990; 11 425-429.

41. Schaloske R, Schlatterer C, Malchow D. A Xestospongin Csensitive $\mathrm{Ca}^{2+}$ store is required for cAMP-induced $\mathrm{Ca}^{2+}$-influx and cAMP-oscillations in Dictyostelium. J Biol Chem 2000; 275 : 8404-8408.

42. Martin JB, Foray MF, Klein G, Satre M. Identification of inositol hexaphosphate in ${ }^{31} \mathrm{P}-\mathrm{NMR}$ spectra of Dictyostelium discoideum amoebae. Relevance to intracellular $\mathrm{pH}$ determination. Biochim Biophys Acta 1987; 931: 16-25.

43. Europe-Finner GN, Gammon B, Newell PC. Accumulation of ${ }^{3} \mathrm{H}-$ inositol into inositol polyphosphates during development of Dictyostelium. Biochem Biophys Res Commun 1991; 181: 191-196.

44. Stephens LR, Hawkins PT, Stanley AF et al. myo-Inositol pentakisphosphates. Biochem J 1991; 275: 485-499.

45. Mayr GW, Radenberg T, Thiel U, Vogel G, Stephens LR. Phosphoinositol diphosphates: non-enzymic formation in vitro and occurrence in vivo in the cellular slime mold Dictyostelium. Carbohydr Res 1992; 234: 247-262.

46. Docampo R, Scott DA, Vercesi AE, Moreno SNJ. Intracellular $\mathrm{Ca}^{2+}$ storage in acidocalcisomes of Trypanosoma cruzi. Biochem $J$ 1995; 310: 1005-1012.

47. Scott DA, de Souza W, Benchimol M et al. Presence of a plantlike proton-pumping pyrophosphatase in acidocalcisomes of Trypanosoma cruzi. J Biol Chem 1998; 273: 22151-22158.

48. Zhang GH, Melvin JE. Secretagogue-induced mobilization of an intracellular $\mathrm{Mg}^{2+}$ pool in rat sublingual mucous acini. J Biol Chem 1992; 267: 20721-20727.

49. Baumann O, Walz B, Somlyo AV, Somlyo AP. Electron probe microanalysis of calcium release and magnesium uptake by endoplasmic reticulum in bee photoreceptors. Proc Natl Acad Sci USA 1991; 88: 741-744.

50. Shaul O, Hilgemann DW, de-Almeida-Engler J, Van Montagu M, Inze D, Galili G. Cloning and characterization of a novel $\mathrm{Mg}^{2+} / \mathrm{H}^{+}$exchanger. EMBO J 1999; 18: 3973-3980. 